\title{
An Estimate of Nest Loss in Canada Due to Industrial Forestry Operations
}

\section{Estimation de la perte de nids attribuable aux activités forestières industrielles au Canada}

\author{
Keith A. Hobson $^{1}$, Amy G. Wilson ${ }^{2}$, Steven L. Van Wilgenburg ${ }^{3}$ and Erin M. Bayne ${ }^{4}$
}

\begin{abstract}
Annual loss of nests by industrial (nonwoodlot) forest harvesting in Canada was estimated using two avian pointcount data sources: (1) the Boreal Avian Monitoring Project (BAM) dataset for provinces operating in this biome and (2) available data summarized for the major (nonboreal) forest regions of British Columbia. Accounting for uncertainty in the proportion of harvest occurring during the breeding season and in avian nesting densities, our estimate ranges from 616 thousand to 2.09 million nests. Estimates of the impact on numbers of individuals recruited into the adult breeding population were made based on the application of survivorship estimates at various stages of the life cycle. Future improvements to this estimate are expected as better and more extensive avian breeding pair density estimates become available and as provincial forestry statistics become more refined, spatially and temporally. The effect of incidental take due to forestry is not uniform and is disproportionately centered in the southern boreal. Those species whose ranges occur primarily in these regions are most at risk for industrial forestry in general and for incidental take in particular. Refinements to the nest loss estimate for industrial forestry in Canada will be achieved primarily through the provision of more accurate estimates of the area of forest harvested annually during the breeding season stratified by forest type and Bird Conservation Region (BCR). A better understanding of survivorship among life-history stages for forest birds would also allow for better modeling of the effect of nest loss on adult recruitment. Finally, models are needed to project legacy effects of forest harvesting on avian populations that take into account forest succession and accompanying cumulative effects of landscape change.
\end{abstract}

RÉSUMÉ. La perte annuelle de nids attribuable à la récolte forestière industrielle (excluant les petits boisés privés) au Canada a été estimée à l'aide de deux sources de dénombrements par points d'écoute : 1) les données du Projet de modélisation de l'avifaune boréale pour les provinces possédant ce biome; et 2) les données compilées dans les principales régions forestières (autres que boréales) de la Colombie-Britannique. En tenant compte de l'incertitude liée à la proportion de la récolte forestière qui s'effectue durant la saison de nidification et aux densités d'oiseaux nicheurs, notre estimation se situe entre 616 milliers et 2,09 millions de nids. Les estimations de l'effet des coupes sur le nombre d'individus recrutés dans la population d'adultes nicheurs ont été fondées sur des estimations de la survie à divers stades du cycle vital. Cette estimation du nombre de nids détruits est appelée à s'améliorer à mesure que de meilleures estimations des densités de couples nicheurs seront disponibles et que les statistiques forestières par province seront révisées, tant spatialement que temporellement. L'effet de la prise accessoire attribuable aux activités forestières n'est pas uniforme et est disproportionnellement centré dans la région boréale sud. Les espèces dont l'aire se concentre dans ces régions sont plus à risque quant aux activités forestières industrielles en général et à la prise accessoire en particulier. L'estimation de la perte de nids attribuable aux activités forestières industrielles au Canada profitera surtout d'estimations plus précises des superficies forestières récoltées annuellement durant la saison de nidification, stratifiées par type forestier et région de conservation des oiseaux. Une compréhension accrue de la survie des oiseaux forestiers aux divers stades du cycle vital permettrait aussi une meilleure modélisation de l'effet de la perte de nids sur le recrutement d'adultes. Enfin, des modèles tenant compte de la succession forestière et des effets cumulatifs de la modification du paysage seront nécessaires pour prévoir les répercussions futures de la récolte forestière sur les populations d'oiseaux.

Key Words: adult recruitment; boreal; commercial forestry; incidental loss; nests

${ }^{1}$ S\&T Branch, Wildlife and Landscape Science Directorate, ${ }^{2}$ Department of Veterinary Medicine, University of Saskatchewan, ${ }^{3}$ Environment Canada,

${ }^{4}$ Department of Biological Sciences, University of Alberta

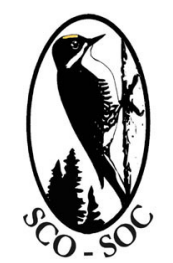

Sponsored by the Society of Canadian Ornithologists and Bird Studies Canada Parrainée par la Société des ornithologistes du Canada et Études d'oiseaux Canada

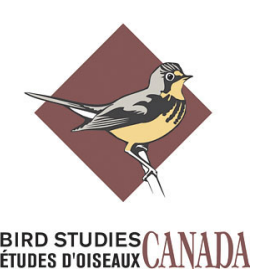


Fig. 1. Distribution of avian point-count samples used in density estimates derived from the Boreal Avian Modeling project (http://www.borealbirds.ca).



\section{INTRODUCTION}

The forests of Canada support some of the highest densities of breeding birds in North America. In aggregate, Canada's forests produce a large proportion of the continent's avifauna (Couturier 2011, Wells and Blancher 2011). The southern portion of Canada's forests in particular are undergoing intense resource development resulting in conservation concerns about potential impacts of industrial operations on birds breeding there (Wells 2011). A dominant source of anthropogenic disturbance in Canada's forests is harvesting for pulp, paper, and timber production. How birds respond to forestry activities has generally focused on numerical and demographic changes caused by the effects that forestry has on the composition (Hobson and Bayne 2000, Cavard et al. 2011), structure (Schieck and Hobson 2000), and spatial pattern of forests (Rempel et al. 2007, Van Wilgenburg and Hobson 2008, Villard et al. 2012) at varying times since harvest (Hobson and Schieck 1999, Schieck and Song 2006). These legacy effects are an important conservation issue for many bird species (Schieck and Song 2006, Cumming et al. 2010).
More recently, the direct loss of birds from the harvesting process has become an additional area of concern. The basic premise for this investigation is that harvesting practices during the breeding season destroy nests incidentally as part of the practice of removing trees, largely, but not exclusively, by clear-cutting and ancillary activities such as hauling, site preparation, and other on-site operations. Legal challenges under the Migratory Bird Convention Act (hereafter MBCA) of this loss have become a controversial issue between the forestry industry and conservation groups but little effort has gone into quantifying the actual risk of loss of migratory bird nests by forest harvesting in Canada during the breeding season. In particular, the implications nest loss has for avian population demography in any given year is not well understood and is important for assessing short- versus longterm risks of forest harvesting on bird populations.

Our objectives were to (1) provide the first comprehensive tally of nests taken incidentally by commercial forestry operations in Canada to inform concerns related to Canada's obligations under the MBCA and (2) estimate the actual consequences of this loss to adult recruitment. Although 
potentially important, we considered events occurring during the nonbreeding season, cumulative effects of landscape change on productivity, and overall mitigation by the industry to be beyond the scope of this exercise. The two main elements required to estimate nest loss by forestry activities are: (1) determining the amount and type of forest harvested during times when birds are breeding and (2) determining the density of nests in the types of forests that are being harvested. In addition, it would be desirable to understand whether the destruction of nests is additive or compensatory to losses from natural processes. We used the best available information with Monte Carlo simulations to generate a range of plausible estimates that incorporate all three determinants of harvesting effects. Numerous types of forestry operations and groups of birds have limited data by which to estimate nest loss. For example, the effects of woodlot management or precommercial or commercial thinning operations are not included because no data are available on seasonal activity patterns of these activities. Nests of resident species like woodpeckers that tend to breed earlier than short-distance and neotropical migrant songbirds throughout much of their range in Canada but are poorly surveyed during point-counts are not included. Similarly, cavity- or ground-nesting waterfowl cannot be included at this time because no density estimates and habitat association data are available at any meaningful spatial scale.

\section{METHODS}

Density estimates were acquired from data collated by the Boreal Avian Modeling Project (hereafter BAM; Cumming et al. 2010). As of September 2012, BAM had combined over 100,000 off-road point-counts from across boreal North America (Fig. 1). Although point-count data were not designed to provide density estimates, BAM has developed and tested various statistical approaches for converting point-counts into densities (Matsuoka et al. 2012, Sólymos et al. 2013). Similarly, we obtained data for $\sim 6100$ point-counts conducted in British Columbia (B.C.; Fig. 1), and analyzed these separately from the BAM data, but using the same methods.

In brief, BAM uses distance sampling to determine the area sampled by point-counts. Through the half-normal binomial estimator, BAM has computed the effective detection radius (EDR) for over 90 species of birds in the boreal forest (Matsuoka et al. 2012). Simultaneously, a modified version of removal modeling (i.e., Farnsworth et al. 2002) was used to compute singing rates. Species-specific singing rates were computed from point counts in BAM where the initial detection of each bird encountered is recorded relative to two or more time intervals (e.g., 0-3, 3-5, 5-10 min). The singing rate is the average rate at which individuals in the population of available birds produce detectable (auditory) clues per unit time interval (1 minute). The resulting singing rate is then transformed into the probability of a bird singing at least one time during the survey (singing probabilities). This accounts for the proportion of birds that were present but missed because they were not singing during the survey. Details on BAM and the statistical corrections are available from the www. borealbirds.ca web site. Combined, these two statistical corrections convert point counts into approximate density estimates that account for differential rates of detection among species and the distance over which species can be heard. Although there are numerous assumptions using this approach, this is the only dataset available for forest birds breeding across the Canadian boreal for which density can be estimated. Very little spot-mapping data is available in the boreal forest and the data that do exist has a strong spatial bias to southern areas. Moreover, Matsuoka et al. (2012) demonstrated that the EDRremoval modeling approach to estimating avian densities is generally comparable to spot-mapping data but may result in slightly higher estimates than spot-mapping in some areas (Rosenberg and Blancher 2005, Confer et al. 2008). In general, developers of the BAM approach to point correction believe it represents an upper-end estimate of density (E. M. Bayne, personal communication).

The second approach we used to estimate density was to use the same BAM dataset but a different denominator when converting counts to density. The method of estimating density is to convert mean counts to densities using the generalized equation:

$$
\text { Density }=\left(\frac{C}{\pi * r^{2}}\right) * 10000
$$

where $C=$ mean count predicted from BAM's regression model, and the radius of the count $(r)$. An alternative approach to the effective detection radius (EDR) is to use the maximum distance detected (hereafter MDD). MDD was developed by Partner's in Flight (hereafter PIF) to estimate population size of North American birds using Breeding Bird Survey data. Matsuoka et al (2012) provided a conversion factor for each species in this analysis that converts BAM density estimates to what would be expected using the MDD approach of PIF. In general, using EDR results in density estimates that are five times higher than MDD. Reviews of PIF density estimates in Canada's forests for abundant species like the Ovenbird (Seiurus aurocapilla) relative to detailed research projects collecting spot-mapping with color-banded individuals (i.e., Bayne and Hobson 2002, Haché and Villard 2010) suggest PIF estimates are likely the lower end of density estimates.

For this investigation, we computed the combined density of 72 species of birds for which density estimates could be accurately computed. An accurate model was defined as one where model convergence occurred for each strata considered and confidence intervals were properly estimated. Specifically, we computed density estimates for the four forest stand types (open mature conifer, open mature deciduous, closed mature conifer, and closed mature deciduous) that 
describe where forestry activities are thought to take place. This was done separately for each Bird Conservation Region(hereafter BCR; NABCI 2000, NABCI Canada 2012) province combination to account for spatial variation in bird abundance. The forest classes were derived from the MODIS Landcover Classification of Canada (hereafter MODIS-LCC; Latifovic et al. 2008). Thus, our strata represent unique combinations of forest stand type and BCR within a province. We calculated weighted mean density estimates for coniferous and deciduous stands for each province, where the contribution of the strata-specific density estimate to the average was weighted by the area of that strata within the given province. We modeled bird density in coniferous and deciduous stand types only rather than by specific tree-types because forest harvesting data was only available at the provincial level as coniferous versus deciduous volume. Age of forest at harvest and the effect of forest age on birds were not available at the time of this analysis at a national scale.

Pairs or number of singing males during the breeding season were assumed to represent a nesting attempt. All boreal species were assumed to have one brood (i.e., 1 nest) per season. Forest birds in southern British Columbia often have more than one brood per season and those data were taken into account for that province only. Refined density estimates by coarse-scale forest type within BCR were summarized by province and then multiplied by estimates of the annual area of harvest estimated for each forest type during the breeding season. Finally, an aggregate tally of nests lost because of forestry activities in Canada was performed by summing data for all provinces and territories.

\section{Nest density}

For the BAM dataset, avian density estimates were available for forest types at greater resolution than could be matched to the cruder forestry harvest data. In addition, avian data were available by BCR but harvest data were available at the provincial scale. As such, assumptions were made concerning the most parsimonious density estimates corresponding to the forest harvest data by creating weighted-averaged estimates in conifer- to deciduous-dominated stand types (Table 1). For example, no discrimination was made between pine- and spruce-dominated stands which often have very different bird densities.

For the B.C. dataset, the nest densities in each B.C. Forestry region were weighted by the proportion of that district which fell into each BCR zone. Densities were calculated at the Forestry region and district level because the B.C. Ministry of Forestry reports all harvest data by forest district or region (Table 2).
Table 1. Estimates of passerine density based on singing males (males/ha) that were used to determine nest density by using regression-based estimates of mean counts converted to densities using maximum detection distance (MDD) and effective detection radius (EDR) based on distance sampling (see Methods), shown by forest type and province (excluding British Columbia). Number of Bird Conservation Regions (BCR) involved in commercial forest areas are given in parentheses. When two BCR values appear, the density estimates were based on the average of the two. Density estimates are derived from BAM point-count data available to March 2009

\begin{tabular}{lccccc}
\hline \hline & \multicolumn{2}{c}{ Coniferous } & & \multicolumn{2}{c}{ Deciduous } \\
\cline { 2 - 3 } \cline { 6 - 6 } Province/Territory (BCR) & MDD & EDR & & MDD & EDR \\
\hline Alberta (6) & 1.5 & 5.4 & & 1.4 & 5.4 \\
Manitoba (6,8) & 0.5 & 1.8 & & 1.2 & 4.7 \\
New Brunswick (14) & 2.4 & 9.1 & & 2.2 & 8.4 \\
Newfoundland (8) & 1.4 & 4.5 & & 3 & 11.3 \\
Nova Scotia (14) & 2.9 & 11.5 & & 3.3 & 12.2 \\
Northwest Territories (6) & 1.4 & 4.5 & & 1.6 & 6.2 \\
Ontario (8) & 2.2 & 7.8 & & 2.4 & 8.9 \\
Prince Edward Island (14) & 2.7 & 10.4 & & 3.2 & 12.1 \\
Québec (8,12) & 2.3 & 8.0 & & 2.7 & 10.4 \\
Saskatchewan (6) & 1.2 & 3.9 & & 1.0 & 4.0 \\
Yukon Territory (4) & 1.0 & 6.2 & & 1.2 & 5.1 \\
\hline
\end{tabular}

Table 2. Estimated mean passerine densities (total passerines/ ha) in each Bird Conservation Region (BCR) zone for British Columbia based on $\sim 6100$ point-counts conducted in British Columbia from 2000-2008. Species such as Brown-headed Cowbirds (Molothrus ater), that do not construct nests, and cliff- or bank-nesting species, with nests unlikely to be destroyed by forestry activities, were not included in these estimates.

\begin{tabular}{lccc}
\hline \hline BCR Zones & $\begin{array}{c}\text { Mean } \\
\text { densities }\end{array}$ & $\begin{array}{c}\text { Error } \\
\text { (SD) }\end{array}$ & $\begin{array}{c}\text { Number of point- } \\
\text { counts }\end{array}$ \\
\hline Boreal Taiga Plains (BTP) & 4.99 & 1.95 & 575 \\
Great Basin (GB) & 7.72 & 3.5 & 251 \\
Northwestern Interior & 3.7 & 1.74 & 134 \\
Forest (NIF) & & & \\
Northern Pacific Rainforest & 7.74 & 3.53 & 890 \\
(NPR) & & & 7952 \\
Northern Rockies (NR) & 6.56 & 3.56 & 9802 \\
Average & 6.71 & 3.62 & \\
\hline
\end{tabular}

\section{Deriving estimates of harvest in Canada by province and forest type}

Once estimates of nest densities were made, it was necessary to derive harvest by area by province. For the boreal, the period 2000 to 2006 was used arbitrarily to provide average estimates 
Table 3. Average annual area of harvest (thousands of hectares) by province/territory, from 2000 to 2006. Proportion conifer and deciduous estimated assuming that these areas were in proportion to timber volumes taken. Forestry statistics were derived from the National Forestry Database (http://nfdp.ccfm.org/dynamic report/dynamic report ui e.php).

\begin{tabular}{|c|c|c|c|c|c|}
\hline \multirow[b]{2}{*}{ Province/Territory } & \multirow[b]{2}{*}{$\begin{array}{l}\text { Average total harvest } \\
\text { (ha } \times 1000)\end{array}$} & \multicolumn{2}{|c|}{ Conifer } & \multicolumn{2}{|c|}{ Deciduous } \\
\hline & & $\begin{array}{c}\text { Proportion of } \\
\text { harvest }\end{array}$ & $\begin{array}{c}\text { Area } \\
\text { (ha } x 1000)\end{array}$ & $\begin{array}{c}\text { Proportion of } \\
\text { harvest }\end{array}$ & $\begin{array}{c}\text { Area } \\
(\text { ha } \times 1000) \\
\end{array}$ \\
\hline Alberta & 79.723 & 0.71 & 55.530 & 0.30 & 23.193 \\
\hline British Columbia & 179.470 & 0.97 & 173.090 & 0.04 & 6.379 \\
\hline Manitoba & 15.133 & 0.68 & 10.257 & 0.32 & 4.877 \\
\hline New Brunswick & 97.674 & 0.67 & 65.666 & 0.33 & 32.007 \\
\hline Northwest Territories & 0.05400 & 1.00 & 0.0540 & 0.00 & 0.00 \\
\hline Ontario & 215.334 & 0.73 & 156.886 & 0.27 & 58.448 \\
\hline Québec & 305.342 & 0.87 & 266.691 & 0.13 & 38.651 \\
\hline Saskatchewan & 26.430 & 0.52 & 13.633 & 0.48 & 12.800 \\
\hline Yukon Territory & 0.057 & 1.00 & 0.0566 & 0.00 & 0.00 \\
\hline Nova Scotia & 52.799 & 0.87 & 45.825 & 0.13 & 6.974 \\
\hline Newfoundland & 22.017 & 0.96 & 21.153 & 0.04 & 0.864 \\
\hline Prince Edward Island & 4.357 & 0.69 & 2.995 & 0.31 & 1.3620 \\
\hline CANADA & 997.388 & 0.81 & 808.0834 & 0.19 & 189.305 \\
\hline
\end{tabular}

of TOTAL HARVEST using Canadian Forest Service summary statistics (http://nfdp.ccfm.org/dynamic report/ dynamic report ui e.php). No harvest data for mixedwoods were available and this necessitated using the simple classifications shown in Table 1. Harvest volumes were converted to area making the assumption that the area of harvest was equivalent to the proportion of the harvest by volume (Table 3, Appendix 1). Thus, for each province we multiplied the total area harvested by the proportional volumes of softwood and hardwood harvested to derive estimated areas of conifer and deciduous forest that was harvested, respectively. More refined estimates were used for British Columbia (Appendices 1 and 2).

\section{Deriving estimates of harvest in British Columbia}

More extensive silvicultural data was available in British Columbia, enabling a more detailed estimate of area harvested during the breeding season for birds. At a broad scale, British Columbia is divided into three forestry regions: Southern Interior Forestry region (SIFR), Coastal Forestry region (CFR), and Northern Interior region (NIFR), and harvest data are available for all of these regions. Estimates of the area harvested in British Columbia were obtained from the National Forest Database (http://nfdp.ccfm.org) for the years of 1990 to 2007. We estimated the timing of the annual harvests based on details reported in harvest volume reports and from the B. C. Ministry of Forestry's Harvest Billing System (HBS). Only forestry activities that occur during the breeding season will result in the incidental take of nests, and because breeding season is shorter in more northern sites, we adjusted the period of breeding disturbance to April to July in forest districts CFR and SIFR, and from May to July in the NIFR. Scaling history records, i.e., records detailing the date that trees were felled, from 1998 to 2008 were compiled and the volume of timber reported felled during the breeding months was summed
(Appendix 2). There may be some deviation between reported and actual felling date, but in the absence of contradictory data or an alternate reporting record, scaling date is an appropriate estimate of monthly patterns in harvesting activity. The average percentage of the annual volume that was harvested during breeding months for each forest region was calculated for the past ten years and that average used to estimate the area harvested during the breeding season.

To determine the number of nests lost during the breeding season, information on the number of nesting attempts for all passerines species included in survey data were compiled (Poole and Gill 2000, Campbell et al. 1997, 2001). On average, passerines in British Columbia have 1.3 nests, with $93 \%$ of surveyed species having fewer than 2 nests.

\section{Deriving incidental take}

For all jurisdictions except British Columbia, the nest loss estimate was derived by multiplying the mean annual (2000-2006) area of deciduous and conifer harvested by the estimated pair densities, i.e., nests. This provided a range in numbers of nests because we had a low and a high estimate of percent harvest during the breeding season (Table 4), as well as two estimates of avian nest density (Table 1).

\section{Incidental take of nests: a recruitment perspective}

From a demographic perspective, not all forms of incidental take are equal in terms of consequences for recruitment into the adult breeding population. Breeding adults are more valuable in this sense than nests or eggs simply because those adults are already contributing to the maintenance of the population. Furthermore, not all nests and eggs will survive and produce young that will return the following year as breeding adults. Although this is not legally relevant in terms of the MBCA, it is worth considering this aspect of loss because it obviously is a fundamental consideration for the 
Table 4. Estimated number of nests destroyed by forestry operations annually, derived by combination of avian nest densities, annual harvest area estimates, and proportion of the annual harvest presumed to occur during the migratory bird breeding season. Min and Max columns correspond to applying the low (MDD) versus high (EDR) density estimates, respectively, as per Table 1. The Low disturbance estimate assumes $12 \%$ of the annual area harvested (from Table 3) occurs during the breeding season following from FPAC (R. Décarie, unpublished manuscript), and the High disturbance estimate assumes that $26 \%$ of the annual area disturbed (from Table 3) occurs during the breeding season, corresponds to the Ontario estimate provided by a submission to the Commission for Environmental Cooperation of North America (CEC 2003).

\begin{tabular}{|c|c|c|c|c|c|c|c|c|c|c|}
\hline \multirow[b]{3}{*}{ Province/Territory } & \multicolumn{4}{|c|}{ Coniferous Forest } & \multicolumn{4}{|c|}{ Deciduous Forest } & \multicolumn{2}{|c|}{ Total Estimate } \\
\hline & \multicolumn{2}{|c|}{$\begin{array}{c}\text { Low } \\
\text { disturbance }\end{array}$} & \multicolumn{2}{|c|}{$\begin{array}{c}\text { High } \\
\text { disturbance }\end{array}$} & \multicolumn{2}{|c|}{$\begin{array}{c}\text { Low } \\
\text { disturbance }\end{array}$} & \multicolumn{2}{|c|}{$\begin{array}{c}\text { High } \\
\text { disturbance }\end{array}$} & \multirow[b]{2}{*}{$\operatorname{Min} \dagger$} & \multirow[b]{2}{*}{$\operatorname{Max} \neq$} \\
\hline & Min & Max & Min & $\operatorname{Max}$ & Min & Max & Min & Max & & \\
\hline Alberta & 9995 & 35,983 & 21,657 & 77,964 & 3896 & 15,029 & 8442 & 32,563 & 13,892 & 110,527 \\
\hline Manitoba & 615 & 2215 & 1333 & 4800 & 702 & 2750 & 1522 & 5959 & 1318 & 10,759 \\
\hline New Brunswick & 18,912 & 71,708 & 40,976 & 155,367 & 8450 & 32,263 & 18,308 & 69,904 & 27,362 & 225,270 \\
\hline Newfoundland & 3554 & 11,423 & 7700 & 24,749 & 311 & 1171 & 674 & 2537 & 3865 & 27,286 \\
\hline Nova Scotia & 15,947 & 63,239 & 34,552 & 137,017 & 2762 & 10,210 & 5984 & 22,121 & 18,709 & 159,138 \\
\hline Northwest Territories & 9 & 29 & 20 & 63 & 0 & 0 & 0 & 0 & 9 & 63 \\
\hline Ontario & 41,418 & 146,845 & 89,739 & 318,165 & 16,833 & 62,422 & 36,471 & 135,248 & 58,251 & 453,413 \\
\hline Prince Edward Island & 970 & 3737 & 2102 & 8098 & 523 & 1978 & 1133 & 4285 & 1493 & 12,383 \\
\hline Québec & 73,607 & 256,023 & 159,481 & 554,717 & 12,523 & 48,237 & 27,133 & 104,513 & 86,130 & 659,230 \\
\hline Saskatchewan & 1963 & 6380 & 4253 & 13,824 & 1536 & 6143 & 3327 & 13,309 & 3499 & 27,133 \\
\hline Yukon Territory & 7 & 42 & 15 & 91 & 0 & 0 & 0 & 0 & 7 & 91 \\
\hline Total§ & 166,997 & 597,625 & 361,828 & $1,294,854$ & 47,536 & 180,203 & 102,994 & 390,440 & 214,533 & $1,685,294$ \\
\hline
\end{tabular}

$\dagger$ Corresponds to adding the Min/Low Disturbance estimates for Conifer and Deciduous forest

\$Corresponds to adding the Max/High Disturbance estimates for Conifer and Deciduous forest

$\S$ Excluding British Columbia

effective conservation of avian forest species and populations. Therefore, we derived estimates of clutch size, nest survival, survival of young to independence, and estimated juvenile overwintering survival from values reported in the literature (Appendix 3). We then used these estimates in a stochastic population model via Monte Carlo simulation to estimate the number of recruits into the population that might be lost because of habitat disturbance. For each combination of province and cover type, we ran a Monte Carlo simulation with 50,000 iterations. Within each iteration, the following steps were performed sequentially:

1. multiply the annual area disturbed by a random uniform number between 0.12 and 0.26 , representing minimum and maximum estimated proportion if habitat disturbance occurring during the breeding season (CEC 2003; R. Décarie, unpublished manuscript) ;

2. multiply result from 1 . by random uniform numbers between our minimum and maximum bird density estimates (Table 1);

3. multiply result from 2 . by a mean clutch size derived via random nonparametric bootstrap estimate $(n-1)$ from data in Appendix 3 within each iteration;

4. multiply result from 3. by mean nest success derived via random nonparametric bootstrap estimate $(n-1)$ from data in Appendix 3 within each iteration;
5. multiply result from 4 . by mean probability of young surviving to independence derived via random nonparametric bootstrap estimate $(\mathrm{n}-1)$ from data in Appendix 3 within each iteration; and

6. multiply result from 5 . by a random uniform number between the minimum and maximum reported values of juvenile overwintering survival probability.

We selected the random uniform numbers for proportion of harvest occurring during the breeding season and bird density estimates because of a lack of data to inform the distribution of those parameters. Thus, the use of random uniform numbers places upper and lower bounds on the estimates without biasing simulated means in medians in a particular direction.

To derive provincial estimates of recruits lost, we summed the result of each iteration across coniferous and deciduous estimates within provinces. Finally, we derived national estimates by summing the results within iterations across provinces.

\section{RESULTS}

Our estimates of incidental take of nests due to commercial forestry showed substantial geographic variation (Table 4), directly proportional to the average annual area harvested by province/territory (Table 3). Combining all data, the annual nest loss estimate for number of nests taken for all provinces 
other than B.C. ranged from 214.5 thousand to 1.69 million depending upon assumed nest densities and proportion of the annual harvest assumed to occur during the breeding season (Table 4). Although the estimates were 2.2 times higher when assuming 26\% of forest harvesting occurred during the breeding season as opposed to $12 \%$, the estimates were even more sensitive to assumed nest densities. Estimates derived based upon MDD ranged from 214.5 thousand to 464.8 thousand (Table 4). In contrast, estimates derived by applying EDR density estimates were $\sim 3.6$ times higher, ranging from 777.8 thousand to 1.69 million (Table 4 ).

\section{The British Columbia data}

The estimates for number of nests taken by industrial forestry in British Columbia were calculated for each forest district region by multiplying the estimated density of breeding females in those districts by the total area harvested and then by the annual number of nests expected from each female (average 1.3 nests/female; Table 5).

Table 5. Estimate of loss of nests due to industrial forestry, and loss of potential adult recruits due to the loss of these nests in each forestry region. NLA stands for 'nest loss area,' which is the sum of areas that are harvested during the breeding season. CFR: Coastal Forest Region, NIFR: Northern Interior Forest region, SIFR: Southern Interior Forestry Region.

\begin{tabular}{ccccc}
\hline \hline $\begin{array}{c}\text { Forest } \\
\text { district } \\
\text { region }\end{array}$ & NLA (ha) & $\begin{array}{c}\text { Female } \\
\text { density/ha }\end{array}$ & $\begin{array}{c}\text { Females in } \\
\text { NLA }\end{array}$ & No. of nests \\
\hline CFR & 24,520 & 7.71 & 189,224 & 245,620 \\
NIFR & 7065 & 4.92 & 34,806 & 44,150 \\
SIFR & 12,672 & 7.09 & 89,898 & 111,656 \\
Total & & & 313,928 & 401,426 \\
\hline
\end{tabular}

Combining estimates from the portion of Canada excluding B.C. with the B.C. estimate provides the best approximation of number of nests lost due to forestry in Canada. Using the low density estimates from MDD, 616 thousand (i.e., 214.5 thousand from the MDD Low Canadian estimate plus 401.4 thousand for the total B.C. estimate [Table 5]) nests are lost annually. The high density estimate is 866 thousand nests (that is, 465 thousand for the High Canadian estimate plus 401.4 thousand for the total B.C. estimate [Tables 5, 6]). In contrast, combining the B.C. estimate with those derived for the rest of Canada based upon the EDR nest density estimate yields $\sim 1.18$ million (i.e., 778 thousand for the HIGH Canadian estimate plus 401.4 thousand for the total B.C. estimate [Table 5]) to 2.09 million (i.e., 1,689 thousand for the HIGH Canadian estimate plus 401.4 thousand for the total B.C. estimate [Table 5]) nests (Table 6). Therefore, a conservative estimate of the range of incidental take of nests due to forestry in Canada given uncertainty in both avian nest densities and proportion of harvest occurring during the breeding season is 616 thousand to 2.09 million nests.
Table 6. Total estimated number of nests destroyed by forestry operations during the migratory bird breeding season by province/territory under differing assumed nesting densities. Low and High correspond to an assumption of 12 and $26 \%$ of annual forest harvesting occurring during the breeding season, respectively (see Methods). Estimates represent sums of estimates presented in Table 4.

\begin{tabular}{lccccc}
\hline \hline & \multicolumn{2}{c}{ MDD } & & \multicolumn{2}{c}{ EDR } \\
\cline { 2 - 3 } \cline { 5 - 6 } Province & Low & High & & Low & High \\
\hline Alberta & 13,892 & 30,099 & & 51,012 & 110,527 \\
Manitoba & 1318 & 2855 & & 4966 & 10,759 \\
New Brunswick & 27,362 & 59,284 & & 103,971 & 225,270 \\
Newfoundland & 3865 & 8373 & & 12,594 & 27,286 \\
Northwest Territories & 9 & 20 & & 29 & 63 \\
Nova Scotia & 18,709 & 40,536 & & 73,448 & 159,138 \\
Ontario & 58,251 & 126,210 & & 209,268 & 453,413 \\
Prince Edward Island & 1493 & 3235 & & 5715 & 12,383 \\
Québec & 86,130 & 186,614 & & 304,260 & 659,230 \\
Saskatchewan & 3499 & 7581 & & 12,523 & 27,133 \\
Yukon Territory & 7 & 15 & & 42 & 91 \\
Subtotal & 214,533 & 464,822 & & 777,828 & $1,685,294$ \\
Total (incl. British & 615,959 & 866,248 & & $1,179,254$ & $2,086,720$
\end{tabular}

Columbia)

MDD = maximum distance detected

$\mathrm{EDR}=$ effective detection radius

Incidental take of nests: a recruitment perspective

Applying the demographic parameters and transition probabilities in our Monte Carlo simulation resulted in slightly lower estimates of the demographic impact of nest loss than suggested by density estimates (Table 7 vs. Table 6). Across Canada, our simulation suggested that between 564 thousand and 1.33 million (range) potential recruits into the population are lost annually (Fig. 2), 90\% of the distribution falling between 732.2 thousand and 1.08 million recruits (Table 7). Similar to nest loss estimates, estimated reductions in recruitment were largely concentrated in those provinces with the highest forest harvesting rates (Table 7).

\section{DISCUSSION}

We provide the first approximation of the number of nests lost annually by industrial forest harvesting operations across Canada. We conservatively estimate the range of potential nests disturbed at between 616 thousand to 2.09 million. However, our estimate of the loss of bird nests in Canada due to forestry is necessarily preliminary and there is much scope for refinement. Fundamentally, our estimates are based on point-count data which were not designed to obtain rigorous estimates of avian nesting density. Density estimates are best determined using spot mapping protocols with color-banding of individuals to determine exact numbers and proportion of territories within sampling areas. Unfortunately, those data are extremely sparse for Canadian forest birds and variation 
Table 7. Estimated reduction in potential adult recruits into the migratory bird population due to the loss of nests owing to forestry operations occurring during the migratory bird breeding season. Estimates represent percentiles of the estimated distribution.

\begin{tabular}{|c|c|c|c|c|c|}
\hline Province & 5 th & 25 th & Median & 75th & 95th \\
\hline Alberta & 20,573 & 29,217 & 37,240 & 46,690 & 61,214 \\
\hline British Columbia & 262,574 & 286,015 & 303,528 & 321,891 & 349,672 \\
\hline Manitoba & 2043 & 2892 & 3642 & 4483 & 5747 \\
\hline New Brunswick & 41,452 & 59,362 & 75,410 & 94,246 & 124,213 \\
\hline Newfoundland & 4824 & 7022 & 9286 & 12,066 & 16,468 \\
\hline Northwest Territories & 10 & 16 & 21 & 28 & 40 \\
\hline Nova Scotia & 26,139 & 38,651 & 52,023 & 68,230 & 93,319 \\
\hline Ontario & 86,180 & 121,493 & 153,634 & 192,060 & 252,086 \\
\hline Prince Edward Island & 2299 & 3265 & 4154 & 5179 & 6751 \\
\hline Québec & 116,929 & 168,910 & 221,352 & 284,989 & 384,031 \\
\hline Saskatchewan & 5336 & 7440 & 9291 & 11,339 & 14,515 \\
\hline Yukon Territory & 9 & 17 & 27 & 38 & 56 \\
\hline CANADA & 732,227 & 818,912 & 887,835 & 963,987 & $1,082,780$ \\
\hline
\end{tabular}

Fig. 2. Distribution of estimated reduction in potential recruitment into the migratory bird population owing to forestry operations conducted during the breeding season. Solid vertical lines encompass inner $50 \%$ of the distribution, whereas dashed lines encompass $90 \%$ of the distribution. Estimates were generated from 50,000 Monte Carlo simulations including estimates of annual area disturbed, proportion of disturbances occurring during the breeding season, and estimated nest densities, plus demographic parameters derived from the literature (see Methods).

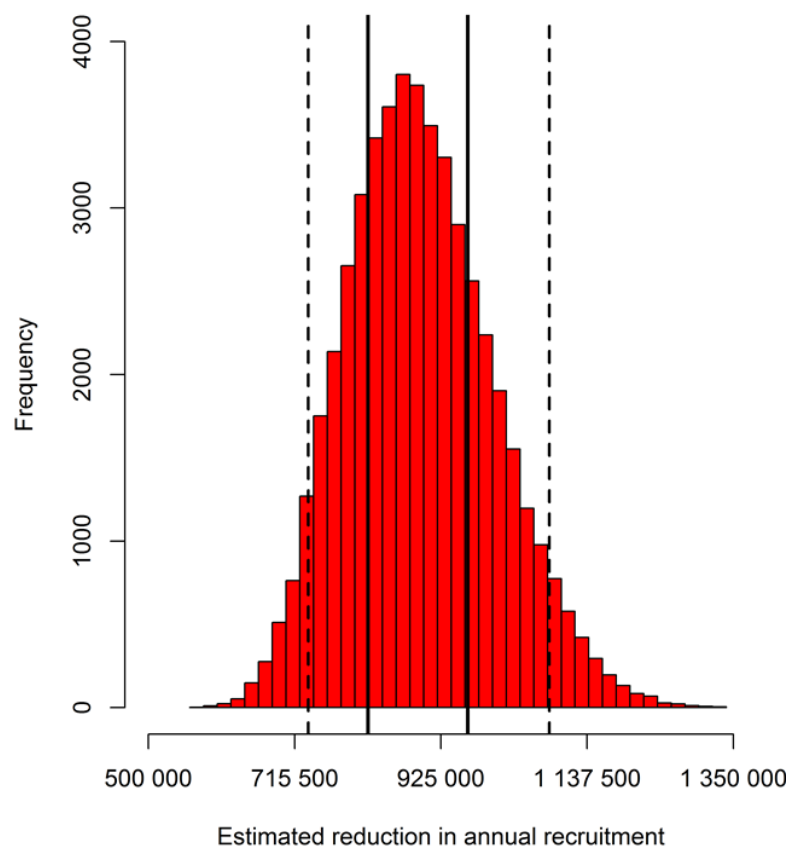

Estimated reduction in annual recruitment among methods in terms of counting birds at the edge of sampling grids often results in high variability using this technique (Kennedy et al. 1999, Savard et al. 2000, Des Granges et al. 2003). Thus, there is no one standard method of estimating density at large spatial scales that does not have some type of bias. A great deal of effort has gone into accounting for the limitations of point-count datasets through the statistical corrections used by MDD and EDR providing an important albeit preliminary range of nests lost. Importantly, we believe that using the MDD and EDR approaches likely provides a lower and upper bound to numbers of nests lost.

Equally limiting are data on forest harvesting. The coarse nature of the amount of forest harvested during the summer months, lack of information on the specific forest types and age classes harvested, and exactly where harvesting occurs spatially prevented us from matching the high resolution bird data that was or is becoming available. There are many reasons why having this information is necessary to get a more refined estimate of nest loss due to forestry operation in Canada. First, summer harvesting often occurs in different forest types than in the winter because of operational constraints imposed by soil moisture or terrain. Operational constraints may bias nest loss estimates in unknown ways depending on how bird density varies between winter and summer harvest. For example, in western Canada many forestry companies harvest upland forests in drier areas that may have lower densities of birds than wetter areas that support greater numbers of birds. Spatially explicit data of harvesting with seasonal patterns are needed within BCRs within each province that account for different types and age classes of forest. This information would allow a much more precise estimate of nest loss because our avian nest density estimates are available at this level of resolution. Quite clearly, the main source of variance in our estimate to date is the lack of more precise information of harvesting schedules, i.e., how much of the provincial totals 
was taken during the breeding season. This results in a rather large range in the expected annual nest loss estimates for industrial forestry activities in Canada. Owing to the lack of good estimates for either densities and proportion of harvest occurring during the breeding season, we chose to model these parameters using random uniform numbers. Obtaining multiple estimates of these parameters would allow the estimation of the distribution that these parameters follow, and thus would greatly improve the precision of our estimates. Given the above major caveats, the data analysis presented here for British Columbia is a good example of the sophisticated level of investigation that can be achieved with appropriate data.

Another source of error in our analysis is that currently no data exist on relative breeding densities of both ground- and cavitynesting migratory waterfowl using the commercial forests. Depending on the extent these species use riparian buffer strips versus upland (commercial) forest, harvesting activities will undoubtedly destroy nests of these species. Other migratory species that are rare or poorly detected by the point-count methodology, e.g., shorebirds, raptors, may also be underestimated. Efforts to collate existing data, as has been done for passerine birds by BAM, would be a good first step to add such information.

\section{Loss of nests: a recruitment perspective}

Estimating nest losses from density of nests alone does not fully describe the effects that the process of forest harvesting has on bird demography. Understanding whether the demographic effects of losing nests to forestry operations is additive or compensatory to natural processes is important. Breeding adults are more valuable in this sense than nests or eggs simply because those adults are already contributing to the maintenance of the population. Whether adult birds are killed by forestry operations has never been studied but most would assume that it does not occur frequently. What happens to adults who are disturbed by forestry operations is also unknown. One possibility is these individuals move into the adjacent forest that is remaining. Whether they try to establish new territories and breed again is not known and likely depends on the stage of the reproductive cycle at which nests are destroyed and the degree to which adjacent stands are already "filled" by breeding conspecifics. Previous work (i.e. Schmiegelow et al. 1997) has demonstrated that in the first year or two after winter-harvesting, migratory birds often pack into remaining forest stands resulting in an unnaturally high density. In some cases this has been shown to result in negative effects on the nesting success of birds in remnant stands because of increased resource competition (Hagan et al. 1996). The same phenomena could occur in stands directly adjacent to summer harvested areas within the year of harvest but has not been tested to the best of our knowledge.
More importantly, not all nests and eggs will survive naturally and produce young that will return the following year as breeding adults. Although this is irrelevant in terms of the MBCA in a legal context, it is worth considering this aspect of nest loss because it obviously is a fundamental consideration for the effective conservation of avian forest species and populations. Future efforts will also be directed at considering legacy effects of changing habitat through forestry, i.e., beyond the immediate issue of destruction of nests, because stands will take many years of succession to revert back into habitat equivalents before harvesting. Alternatively, the change in habitat due to forestry creates new habitat for some (early successional) species while destroying that of others. The temporal dynamic of disturbance regimes like forestry makes it an ideal case to consider legacy effects of habitat supply.

Currently, the biggest challenge to using a recruitment perspective in estimates of incidental take is clearly the paucity of information on actual survival during various stages of the life cycle of migratory forest birds. In addition, it is currently not clear if survivorship will differ between birds that failed to breed or were delayed because of nest loss and those that were not disturbed by forestry operations. Estimates of overwinter survivorship may be too low if density-dependent factors occur on the wintering grounds and survivors do better with fewer conspecifics. The currency of adult recruits versus nests lost is more useful, especially when comparing the effects of incidental take occurring in different industrial sectors.

\section{Putting the Canadian forestry nest loss into perspective}

The estimate of 616 thousand to 2.09 million nests of migratory birds destroyed annually by forestry conducted during the breeding season requires some perspective. We have demonstrated that this corresponds to a much lower impact on the number of adults recruited into the breeding population the following year simply because not all nests are naturally successful and mortality occurs between fledging and ultimate recruitment. By considering the number of recruits, we have demonstrated that these nests may correspond to perhaps half that number of the expected recruiting adults (Loss et al. 2012). Conversion of nests lost into the number of potential recruits lost from the population allows more direct comparison of forestry related take with other sources of avian mortality (Calvert et al. 2013).

With some exceptions, most industrial forestry operations in Canada have occurred in the southern boreal (mixedwoods). Therefore, the majority of concern about nest loss due to forestry should be directed at those species whose ranges primarily occupy those more southern regions. Loss of nests of common species may also be of less concern than those of rarer species, although that would need to be examined on a 
case-by-case basis. Currently, we do not have the distributional and demographic data of Canadian forest birds to allow an understanding of just what the estimate of 616 thousand to 2.09 million nests lost due to industrial forestry means in terms of actual conservation and management priorities, particularly at a species level.

The BAM dataset allows a ranking of species by density of singing males by broad forest type. These sorts of data considered in a national context could serve as a guide to consider which regions of the commercial forest require high scrutiny both in terms of incidental nest loss and in terms of conservation needs in general. Appendix 4 summarizes for some forest birds, in which BCR and province the highest density of singing males occurs nationally by species and how this density varies across forest types. This table shows high variation among species in their apparently preferred habitats and so demonstrates the complexities involved in interpreting a single overall estimate for nests lost for all species in terms of species-specific impacts or conservation measures. Different species often have different centers of distribution in Canadian forests and BCR. Loss of nests due to forestry may warrant additional concern for species of national or regional conservation concern in regions with significant centers of population abundance, e.g., Canada Warbler (CAWA; Cardellina canadensis) in Manitoba BCR 6; Cape May Warbler (CMWA; Setophaga tigrina) in BCR 8 in Saskatchewan; and Black-throated Green Warbler (BTNW; Setophaga virens) in BCR 14 in Québec (NABCI Canada 2012). Of course, forestry practices outside the breeding season and the overall habitat quality and supply scenario for these species at those locations and nationally should be the primary concern.

\section{CONCLUSION}

Breeding bird densities for major forest cover types in Canada need to be refined. This would likely require the establishment of many new spot mapping grids across Canada's forests. If these grids also involved the use of point-counts by observer or using microphone techniques, then this would inform estimates of error associated with density estimates using point-counts as used here.

A summary of all available spot mapping data for forest birds in Canada needs to be compiled. Where possible, these data should be compared with density estimates derived from pointcount data for the same forest regions and cover types. These data should be used to refine nest loss estimates. A more standardized way of dealing with density estimates based on partial territory overlap will be required, however, to make such a comparison robust among different regions.

Variance associated with numerous parameters used in the nest loss estimates derived here need to be measured or estimated and this error propagated. Currently, the largest contributor to variance in the forestry nest loss estimate is uncertainty associated with the proportion of harvest taking place during the breeding season. This swamps all other uncertainty and so until the timing of harvest can be better determined, there is little point in trying to refine more minor contributions to variance. Hopefully, this will change as industry and provincial governments provide these data.

Greater access to provincial/industry forestry data in a spatially explicit format is needed. Only then can estimates of nests lost at a provincial level be spatially associated with forest cover types and BCR within provinces. Estimates of actual areas cut (vs. volumes of timber) are needed. It is possible some of these data requirements could be obtained using remote sensing.

Refinements to nest loss estimates can be made by incorporating those factors known to alter breeding bird densities, e.g., spruce budworm outbreaks, bark beetle infestations, in a spatially explicit modeling framework.

Responses to this article can be read online at:

http://www.ace-eco.org/issues/responses.php/583

\section{Acknowledgments:}

Thanks to Craig Machtans and Martin Raillard for help with numerous aspects of this exercise. B.C. data was kindly provided by Dr. Lepage, Drs. K. Martin and M. Drever, Dr. P. Arcese, K. Jewell, F. Corbould, M. Preston, K. Stuart-Smith, A. Tyrell, D. Seips, and R. Pojar. We gratefully acknowledge the BAM Project funding and data partners, and Technical Committee members who made this project possible. A full list of the hundreds of people participating in this project can be found at www.borealbirds.ca. Drs. Jean Pierre Savard and Kathy Martin provided valuable comments on an earlier draft of this report. We also thank the Revenue Branch in the $B C$ Ministry of Forests \& Range for helpful assistance navigating online resources. The paper was improved by critical comments of D. Ryan Norris, the subject editor, and two anonymous reviewers.

\section{LITERATURE CITED}

Adams, A. A. Y., S. K. Skagen, and R. D. Adams. 2001. Movements and survival of Lark Bunting fledglings. Condor 103:643-647.

Adams, A. A. Y., S. K. Skagen, and J. A. Savidge. 2007. Population-specific demographic estimates provide insights into declines of lark buntings (Calamospiza melanocorys). Auk 124:578-593. http://dx.doi.org/10.1642/0004-8038(2007) 124[578:PDEPII]2.0.CO;2 
Anders, A. D., D. C. Dearborn, J. Faaborg, and F. R. Thompson III. 1997. Juvenile survival in a population of neotropical migrant birds. Conservation Biology 11:698-707. http://dx. doi.org/10.1046/j.1523-1739.1997.95526.x

Bayne, E. M., and K. A. Hobson. 2002. Apparent survival of male Ovenbirds in fragmented and forested boreal landscapes. Ecology 83:1307-1316. http://dx.doi.org/10.1890/0012-9658 (2002)083[1307:ASOMOI]2.0.CO;2

Bourque, J., and M.-A. Villard. 2001. Effects of selection cutting and landscape-scale harvesting on the reproductive success of two neotropical migrant bird species. Conservation Biology 15:184-195.

Buehler, D. A., J. J. Giocomo, J. Jones, P. B. Hamel, C. M. Rogers, T. A. Beachy, D. W. Varble, C. P. Nicholson, K. L. Roth, J. Barg, R. J. Robertson, J. R. Robb, and K. Islam. 2008. Cerulean warbler reproduction, survival, and models of population decline. Journal of Wildlife Management 72 (3):646-653. http://dx.doi.org/10.2193/2006-339

Bulluck, L. P., and D. A. Buehler. 2008. Factors influencing Golden-winged Warbler (Vermivora chrysoptera) nest-site selection and nest survival in the Cumberland Mountains of Tennessee. Auk 125:551-559. http://dx.doi.org/10.1525/ auk.2008.07075

Calvert, A. M., C. A. Bishop, R. D. Elliot, E. A. Krebs, T. M. Kydd, C. S. Machtans, and G. J. Robertson. 2013. A synthesis of human-related avian mortality in Canada. Avian Conservation and Ecology 8(2): 11. http://dx.doi.org/10.5751/ ACE-00581-080211

Campbell, R. W., N. K. Dawe, I. McTaggart- Cowan, J. M. Cooper, G. W. Kaiser, M. C. E. McNall, and G. E. J. Smith. 1997. The birds of British Columbia. Volume 3. University of British Columbia Press, Vancouver, British Columbia, Canada.

Campbell, R. W., G. E. J. Smith, M. C. E. McNall, G. W. Kaiser, J. M. Cooper, I. McTaggart-Cowan, and N. K. Dawe. 2001. The birds of British Columbia. Volume 4. University of British Columbia Press, Vancouver, British Columbia, Canada.

Cavard, X., S. E. Macdonald, Y. Bergeron, and H. Y. H. Chen. 2011. Importance of mixedwoods for biodiversity conservation: evidence for understory plants, songbirds, soil fauna, and ectomycorrhizae in northern forests. Environmental Reviews 19:142-161. http://dx.doi.org/10.1139/a11-004

Chapa-Vargas, L., and S. K. Robinson. 2006. Nesting success of a songbird in a complex floodplain forest landscape in Illinois, USA: Local fragmentation vs. vegetation structure. Landscape Ecology 21:525-537. http://dx.doi.org/10.1007/ s10980-005-2894-7
Chapa-Vargas, L., and S. K. Robinson. 2007. Nesting success of Acadian Flycatchers (Empidonax virescens) in floodplain forest corridors. Auk 124:1267-1280. http://dx.doi. org/10.1642/0004-8038(2007)124[1267:NSOAFE]2.0.CO;2

Commission for Environmental Cooperation of North America (CEC). 2003. Factual Record Ontario Logging Submission (SEM-02-001). CEC, Montréal, Québec, Canada.

Confer, J. L., R. E. Serrell, M. Hagar, and E. Lahr. 2008. Field tests of the Rosenberg-Blancher method for converting point counts to abundance estimates. Auk 125:932-938. http://dx. doi.org/10.1525/auk.2008.06263

Couturier, A. R. 2011. Geospatial modeling of abundance with breeding birds atlas data. Pages 63-72 in J. V. Wells, editor. Boreal birds of North America: a hemispheric view of their conservation links and significance. Studies in avian biology 41. University of California Press, Berkeley, California, USA.

Cumming, S. G., K. Lefevre, E. Bayne, T. Fontaine, F. K. A. Schmiegelow, and S. J. Song. 2010. Toward conservation of Canada's boreal forest avifauna: design and application of ecological models at continental extents. Avian Conservation and Ecology 5(2): 8. http://dx.doi.org/10.5751/ACE-00406-050208

Dalley, K. L., P. D. Taylor, and D. Shutler. 2008. Nest-site characteristics and breeding success of three species of boreal songbirds in western Newfoundland, Canada. Canadian Journal of Zoology 86:1203-1211. http://dx.doi.org/10.1139/ Z08-104

DesGranges, J.-L., Y. Grégoire, P. Belleau, P. Agin, and L. Coté. 2003. Identification d'aires prioritaires de conservation par l'analyse de la diversité aviaire: le cas des forêts du Bas St-Laurent. Technical Report Series No. 386, Canadian Wildlife Service, Quebec, Quebec, Canada.

Dhondt, A. A. 1979. Summer dispersal and survival of juvenile Great Tits in southern Sweden. Oecologia 42:139-157. http:// dx.doi.org/10.1007/BF00344854

Duguay, J. P., P. B. Wood, and J. V. Nichols. 2001. Songbird abundance and avian nest survival rates in forests fragmented by different silvicultural treatments. Conservation Biology 15:1405-1415.

Farnsworth, G., K. H. Pollock, J. D.. Nichols, T. R Simons, J. E. Hines, and J. R. Sauer. 2002. A removal model for estimating the detection probability during point counts divided into time intervals. Auk 119:414-425.

Fauth, P. T. 2000. Reproductive success of Wood Thrushes in forest fragments in northern Indiana. Auk 117:194-204. http:// dx.doi.org/10.1642/0004-8038(2000)117[0194:RSOWTI]2.0. $\mathrm{CO} ; 2$ 
Fauth, P. T., and P. R. Cabe. 2005. Reproductive success of Acadian Flycatchers in the Blue Ridge mountains of Virginia. Journal of Field Ornithology 76:150-157.

Gram, W. K., P. A. Porneluzi, R. L. Clawson, J. Faaborg, and S. C. Richter. 2003. Effects of experimental forest management on density and nesting success of bird species in Missouri Ozark Forests. Conservation Biology 17:1324-1337. http://dx.doi.org/10.1046/j.1523-1739.2003.02171.x

Grant, T. A., E. M. Madden, T. L. Shaffer, P. J. Pietz, G. B. Berkey, and N. J. Kadrmas. 2006. Nest survival of Claycolored and Vesper Sparrows in relation to woodland edge in mixed-grass prairies. Journal of Wildlife Management 70:691-701. http://dx.doi.org/10.2193/0022-541X(2006)70 [691:NSOCAV]2.0.CO;2

Haché, S., and M.-A. Villard. 2010. Age-specific response of a migratory bird to an experimental alteration of its habitat. Journal of Animal Ecology 79:897-905.

Hagan, J. M., W. M. V. Haegen, and P. S. McKinley. 1996. The early development of forest fragmentation effects on birds. Conservation Biology 10:188-202. http://dx.doi. org/10.1046/j.1523-1739.1996.10010188.x

Hobson, K. A., and E. Bayne. 2000. Breeding bird communities in boreal forest of western Canada: consequences of "unmixing" the mixedwoods. Condor 102:759-769.

Hobson, K. A., and J. Schieck. 1999. Changes in bird communities in boreal mixedwood forest: harvest and wildfire effects over 30 years. Ecological Applications 9:849-863. http://dx.doi.org/10.1890/1051-0761(1999)009[0849:CIBCIB] 2.0.CO;2

Holmes, R. T., P. P. Marra, and T. W. Sherry. 1996. Habitatspecific demography of breeding Black-throated Blue Warblers (Dendroica caerulescens): implications for population dynamics. Journal of Animal Ecology 65:183-195. http://dx.doi.org/10.2307/5721

Hoover, J. P., M. C. Brittingham, and L. J. Goodrich. 1995. Effects of forest patch size on nesting success of wood thrushes. Auk 112:146-155. http://dx.doi.org/10.2307/4088774

Kaiser, S. A., and C. A. Lindell. 2007. Effects of distance to edge and edge type on nestling growth and nest survival in the wood thrush. Condor 109:288-303. http://dx.doi. org/10.1650/0010-5422(2007)109[288:EODTEA]2.0.CO;2

Kennedy, J. A., P. Dilworth-Christie, and A. J. Erskine. 1999. The Canadian breeding bird (mapping) census database. Technical Report Series 342, Canadian Wildlife Service, Ottawa, Ontario, Canada.

Kershner, E. L., Walk, J. W., and R. E. Warner. 2004. Postfledging movements and survival of juvenile Eastern Meadowlarks (Sturnella magna) in Illinois. Auk 121:1146-1154.
King, D. I., and R. M. DeGraaf. 2002. The effect of forest roads on the reproductive success of forest-dwelling passerine birds. Forest Science 48:391-396.

King, D. I., R. M. DeGraaf, M. L. Smith, and J. P. Buonaccorsi. 2006. Habitat selection and habitat-specific survival of fledgling Ovenbirds (Seiurus aurocapilla). Journal of Zoology 269:414-429. http://dx.doi.org/10.1111/j.1469-7998.2006.00158. $\underline{\mathrm{X}}$

King, D. I., C. R. Griffin, and R. M. DeGraaf. 1996. Effects of clearcutting on habitat use and reproductive success of the ovenbird in forested landscapes. Conservation Biology 10:1380-1386. http://dx.doi.org/10.1046/j.1523-1739.1996.10051380. $\underline{\mathrm{X}}$

Knutson, M. G., R. K. Hines, L. A. Powell, M. A. Friberg, and G. J. Niemi. 2006. An assessment of bird habitat quality using population growth rates. Condor 108:301-314. http://dx.doi. org/10.1650/0010-5422(2006)108[301:AAOBHQ]2.0.CO;2

Kostecke, R. M., and D. A. Cimprich. 2008. Adult and juvenile survival of Black-capped Vireos within a large breeding population in Texas. Condor 2:251-259. http://dx.doi. org/10.1525/cond.2008.8459

Latifovic, R., I. Olthof, D. Pouliot, and J. Beaubien. 2008. Land cover map of Canada 2005 at 250m spatial resolution. Natural Resources Canada/Earth Sciences Sector Program/ Canada Centre for Remote Sensing, Ottawa, Ontario, Canada. [online] URL: ftp://ftp.ccrs.nrcan.gc.ca/ad/NLCCLandCover/ LandcoverCanada2005 250m

Loss, S. R., T. Will, and P. P. Marra. 2012. Direct humancaused mortality of birds: improving quantification of magnitude and assessment of population impact. Frontiers in Ecology and the Environment 10:357-364. http://dx.doi. org/10.1890/110251

Matsuoka, S. M., E. M. Bayne, P. Sólymos, P. C. Fontaine, S. G. Cumming, F. K. A Schmiegelow, and S. J. Song. 2012. Using binomial distance-sampling methods to estimate the effective detection radius of point-count surveys across boreal Canada. Auk 129:268-282. http://dx.doi.org/10.1525/auk.2012.11190

North American Bird Conservation Initiative (NABCI). 2000. Bird conservation region descriptions. A supplement to the North American Bird Conservation Initiative, Bird Conservation Region Map. U.S. NABCICommittee, U.S. Fish and Wildlife, Arlington, Virginia, USA.

North American Bird Conservation Initiative Canada (NABCI). 2012. The state of Canada's Birds, 2012. Environment Canada, Ottawa, Canada. 36 pages.

Peak, R. G., F. R. Thompson, and T. L. Shaffer. 2004. Factors affecting songbird nest survival in riparian forests in a midwestern agricultural landscape. Auk 121:726-737. 
Pidgeon, A. M., V. C. Radeloff, and N. E. Mathews. 2006. Contrasting measures of fitness to classify habitat quality for the Black-throated Sparrow (Amphispiza bilineata). Biological Conservation 132:199-210. http://dx.doi.org/10.1016/ j.biocon.2006.03.024

Poole, A., and F. Gill, editors. 1992-2000. Birds of North America, Numbers 1-560. Academy of Natural Sciences, Philadelphia, Pennsylvania, USA, and American Ornithologists' Union, Washington, D.C., USA.

Porneluzi, P. A., and J. Faaborg. 1999. Season-long fecundity, survival, and viability of Ovenbirds in fragmented and unfragmented landscapes. Conservation Biology 13:1151-1161. http://dx.doi.org/10.1046/j.1523-1739.1999.98455.x

Powell, L. A., M. J. Conroy, D. G. Krementz, and J. D. Lang. 1999. A model to predict breeding-season productivity for multibrooded songbirds. Auk 116:1001-1008. http://dx.doi. org $/ 10.2307 / 4089680$

Pyle, P., and D. DeSante. 2012. List of North American birds and alpha codes according to American Ornithologists' Union taxonomy through the 53rd AOU Supplement. The Institute for Bird Populations, Point Reyes Station, California, USA. [online] URL: http://www.birdpop.org/alphacodes.htm

Reidy, J. L., M. M. Stake, and F. R. Thompson. 2008. Goldencheeked warbler nest mortality and predators in urban and rural landscapes. Condor 110:458-466. http://dx.doi. org/10.1525/cond.2008.8473

Rempel, R. S., J. Baker, P. C. Elkie, M. J. Gluck, J. Jackson, R. S. Kushneriuk, T. Moore, and A. H. Perera. 2007. Forest policy scenario analysis: sensitivity of songbird community to changes in forest cover amount and configuration. Avian Conservation and Ecology 2(1): 5. [online] URL: http://www. ace-eco.org/vol2/iss1/art5/

Rosenberg, K. V., and P. J. Blancher. 2005. Setting numerical population objectives for priority landbird species. Pages 57-67 in C. J. Ralph and T. D. Rich, editors. Bird conservation implementation and integration in the Americas: proceedings of the Third International Partners in Flight Conference, vol. 1. Forest Service General Technical Report PSW-GTR-191. U.S. Department of Agriculture, Washington, D.C., USA.

Rush, S. A., and B. J. M. Stutchbury. 2008. Survival of fledgling Hooded Warblers (Wilsonia citrina) in small and large forest fragments. Auk 125:183-191. http://dx.doi. org/10.1525/auk.2008.125.1.183

Savard, J.-P. L., D. R. Seip, and L. Waterhouse. 2000. Avian diversity in relation to logging in the coastal rainforests of British Columbia. Technical Report Series 349. Canadian Wildlife Service, Pacific and Yukon Region, Vancouver, British Columbia, Canada.
Schieck, J., and K. A. Hobson. 2000. Bird communities associated with live residual tree patches within cut blocks and burned habitat in mixedwood boreal forests. Canadian Journal of Forest Research 30:1281-1295. http://dx.doi. org/10.1139/x00-061

Schieck, J., and S. J. Song. 2006. Changes in bird communities throughout succession following fire and harvest in boreal forests of western North America: literature review and metaanalyses. Canadian Journal of Forest Research 36:1299-1318. http://dx.doi.org/10.1139/x06-017

Schmidt, K. A., S. A. Rush, and R. S. Ostfeld. 2008. Wood thrush nest success and post-fledging survival across a temporal pulse of small mammal abundance in an oak forest. Journal of Animal Ecology 77:830-837. http://dx.doi. org/10.1111/j.1365-2656.2008.01378.x

Schmiegelow, F. K. A., C. S. Machtans, and S. J. Hannon. 1997. Are boreal birds resilient to forest fragmentation? An experimental study of short-term community responses. Ecology 78:1914-1932. http://dx.doi.org/10.1890/0012-9658 (1997)078[1914:ABBRTF]2.0.CO;2

Simons, T. R., G. L. Farnsworth, and S. A. Shriner. 2000. Evaluating Great Smoky Mountains National Park as a population source for the Wood Thrush. Conservation Biology 14:1133-1144. http://dx.doi.org/10.1046/j.1523-1739.2000.98606. $\underline{\mathrm{X}}$

Sólymos, P., S. M. Matsuoka, E. M. Bayne, S. R. Lele, P. Fontaine, S. G. Cumming, D. Stralberg, F. K. A. Schmiegelow, S. J. Song. 2013. Calibrating indices of avian density from non-standardized survey data: making the most of a messy situation. Methods in Ecology and Evolution. http://dx.doi. org/10.1111/2041-210X.12106

Sullivan, K. A. 1989. Predation and starvation: age-specific mortality in juvenile juncos (Junco phaenotus). Journal of Animal Ecology 58:275-286. http://dx.doi.org/10.2307/5000

Twedt, D. J., R. R. Wilson, J. L. Henne-Kerr, and D. A. Grosshuesch. 2002. Avian response to bottomland hardwood reforestation: the first 10 years. Restoration Ecology 10:645-655. http://dx.doi.org/10.1046/j.1526-100X.2002.01045. $\underline{x}$

Twedt, D. J., R. R. Wilson, J. L. Henne-Kerr, and R. B. Hamilton. 2001. Nest survival of forest birds in the Mississippi Alluvial Valley. Journal of Wildlife Management 65:450-460. http://dx.doi.org/10.2307/3803097

Van Wilgenburg, S. L., and K. A. Hobson. 2008. Landscapescale disturbance and boreal forest birds: can large single-pass harvest approximate fires? Forest Ecology and Management 256:136-146. http://dx.doi.org/10.1016/j.foreco.2008.04.017 
Villard, M.-A., E. D’Astous, S. Haché, J.-F. Poulin, and S. Thériault. 2012. Do we create ecological traps when trying to emulate natural disturbances? A test on songbirds of the northern hardwood forest. Canadian Journal of Forest Research 42:1213-1219. http://dx.doi.org/10.1139/x2012-047

Ward, M. P. 2005. The role of immigration in the decline of an isolated migratory bird population. Conservation Biology 19:1528-1536. http://dx.doi.org/10.1111/j.1523-1739.2005.00245. $\underline{\mathrm{X}}$

Ward, D., and J. N. M. Smith. 2000. Brown-headed Cowbird parasitism results in a sink population in Warbling Vireos. Auk 117:337-344.

Weakland, C. A., P. B. Wood, and W. M. Ford. 2002. Responses of songbirds to diameter-limit cutting in the central Appalachians of West Virginia, USA. Forest Ecology and Management 155:115-129. http://dx.doi.org/10.1016/ S0378-1127(01)00552-7

Wells, J. V. 2011. Boreal forest threats and conservation status. Pages 1-6 in J. V. Wells, editor. Boreal birds of North America: $a$ hemispheric view of their conservation links and significance. Studies in avian biology no. 41. University of California Press, Berkeley, California, USA.

Wells, J. V. and P. Blancher. 2011. Global role for sustaining bird populations. Pages 7-21 in J. V. Wells, editor. Boreal birds of North America: a hemispheric view of their conservation links and significance. Studies in avian biology no. 41. University of California Press, Berkeley, California, USA.

Wells, K. M. S., M. R. Ryan, J. J. Millspaugh, F. R. Thompson III, and M. W. Hubbard. 2007. Survival of postfledging grassland birds in Missouri. Condor 109:781-794. http://dx. doi.org/10.1650/0010-5422(2007)109[781:SOPGBI]2.0.CO;2

Willson, M. F. 1966. Breeding ecology of the Yellow-headed Blackbird. Ecological Monographs 36:51-77. http://dx.doi. org/10.2307/1948488 
Appendix 1. Provincial forest harvest volume estimates.

Table A1.1 Harvest data as volume estimates (thousand $\mathrm{m}^{3}$ ). These data were used to calculate percent conifer and deciduous harvests by area in Table 2. Data derived from Canadian Forest Service summary statistics http://nfdp.ccfm.org/dynamic_report/dynamic_report_ui_e.php

\begin{tabular}{|c|c|c|c|}
\hline Province/Territory & Vol Softwood & Vol Hardwood & Total \\
\hline Alberta & 14876.00 & 6890.28 & 2436.00 \\
\hline British Columbia & 75428.90 & 2787.04 & \\
\hline Manitoba & 1513.26 & 714.38 & 2227.64 \\
\hline New Brunswick & 7125.15 & 3478.98 & 10604.13 \\
\hline Northwest Territories & 24.19 & 0 & 24.19 \\
\hline Ontario & 17904.11 & 6687.26 & 24591.38 \\
\hline Québec & 30007.85 & 4674.03 & 34681.88 \\
\hline Saskatchewan & 2422.01 & 2214.92 & 4636.94 \\
\hline Yukon Territory & 30.68 & 0 & 30.68 \\
\hline Nova Scotia & 5350.12 & 814.27 & 6169.39 \\
\hline Newfoundland & 2341.59 & 94.41 & 2436.00 \\
\hline Prince Edward Island & 438.75 & 197.59 & 636.36 \\
\hline CANADA & 157462.6 & 36836.15 & 194298.75 \\
\hline
\end{tabular}


Appendix 2. British Columbia Harvest trends by year and region.

Figure A2.1. Annual variation in the percentage of the timber volume harvested during active breeding periods across the Coastal (CFR), Northern Interior (NIFR) and Southern Interior (SIFR) Forest Districts averaged across 1998-2008. Data obtained from the BC Ministry of Forestry's Harvest Billing System (HBS), [http://www.for.gov.bc.ca/hva/hbs]

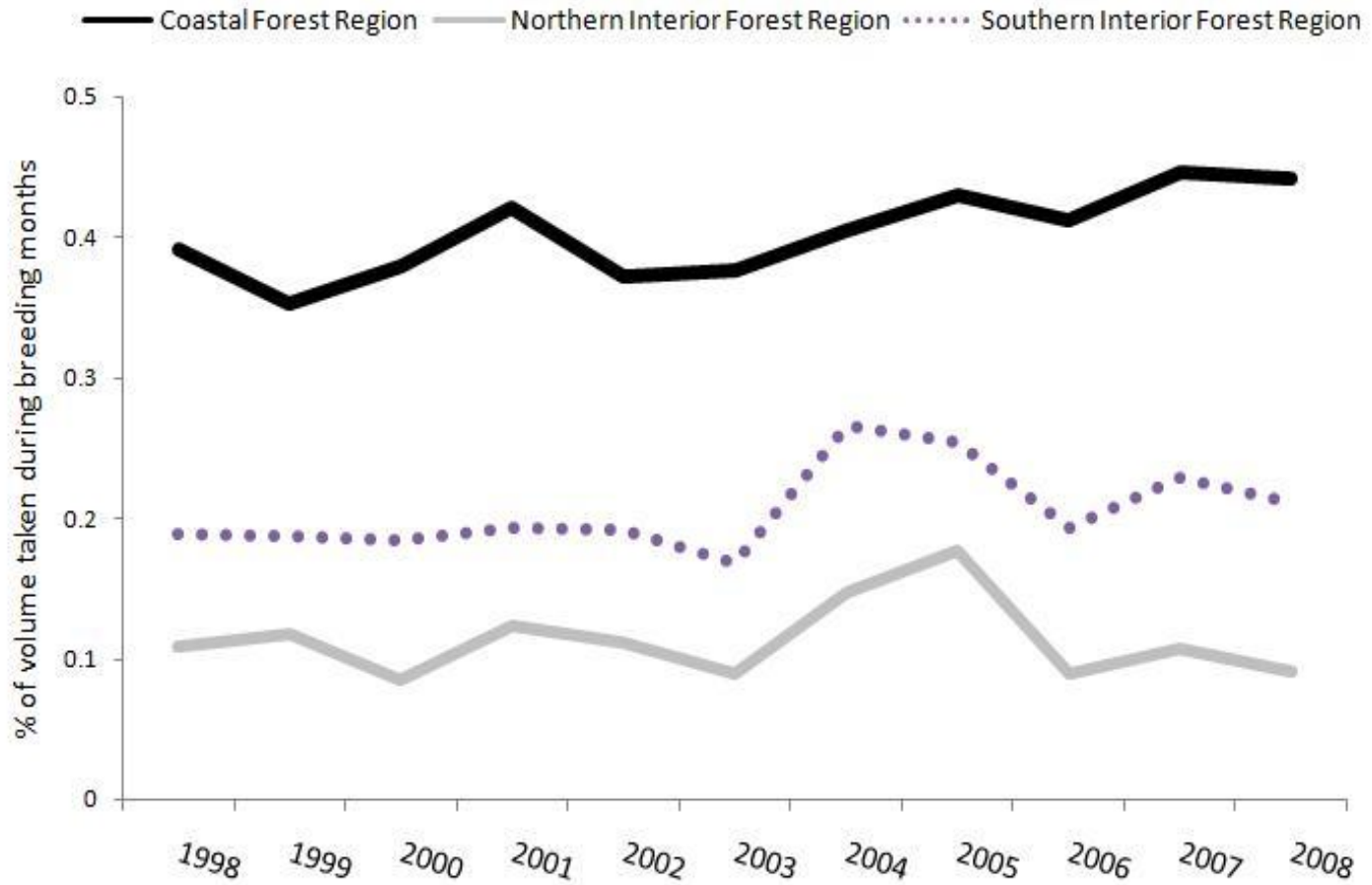


Appendix 3. Avian demographic parameters.

Table A3.1. Peer-reviewed sources of songbird demographic parameters used in incidental take estimates and mean estimates across studies. Species codes are according to the AOU 2012 (Pyle and De Sante 2012). Note: estimates used in the Monte Carlo simulation model corresponded to values from individual studies, not the summary data presented here.

\begin{tabular}{|c|c|c|c|c|}
\hline Species & $\begin{array}{l}\text { Avg. } \\
\text { Nest } \\
\text { Surv\% }\end{array}$ & Nest Survival Reference(s) & $\begin{array}{c}\text { FY/nest } \\
\dagger\end{array}$ & FY/nest Reference(s) \\
\hline ACFL & 0.61 & $\begin{array}{l}\text { Duguay et al. (2001), Twedt et al. } \\
\text { (2002), Gram et al. (2003), Peak } \\
\text { et al. (2004), Fauth \& Cabe } \\
\text { (2005), Knutson et al. (2006), } \\
\text { Chapa-Vargas \& Robinson (2006, } \\
\text { 2007) }\end{array}$ & & \\
\hline AMRE & 0.53 & $\begin{array}{l}\text { Duguay et al. (2001), Knutson et } \\
\text { al. (2006) }\end{array}$ & & \\
\hline AMRO & 0.33 & $\begin{array}{l}\text { Duguay et al. (2001), Knutson et } \\
\text { al. (2006) }\end{array}$ & & \\
\hline BAOR & 0.86 & $\begin{array}{l}\text { Twedt et al. (2002), Knutson et al. } \\
\text { (2006) }\end{array}$ & & \\
\hline $\mathrm{BCCH}$ & 0.69 & Knutson et al. (2006) & & \\
\hline BGGN & 0.54 & $\begin{array}{l}\text { Twedt et al. }(2001,2002) \text {, } \\
\text { Knutson et al. }(2006)\end{array}$ & & \\
\hline BLPW & 0.76 & Dalley et al. (2008) & & \\
\hline BRTH & 0.79 & $\begin{array}{l}\text { Twedt et al. (2002), Knutson et al. } \\
\text { (2006) }\end{array}$ & & \\
\hline BTBW & 0.38 & $\begin{array}{l}\text { Holmes et al. (1996), Duguay et } \\
\text { al. (2001), Bourque \& Villard } \\
\text { (2001) }\end{array}$ & & \\
\hline BTSP & 0.24 & Pidgeon et al. (2006) & 2.37 & Pidgeon et al. (2006) \\
\hline CAWR & 0.93 & Twedt et al. (2002) & & \\
\hline CCSP & 0.30 & Grant et al. (2006) & & \\
\hline CERW & 0.32 & Buehler et al. (2008) & 2.50 & Buehler et al. (2008) \\
\hline COYE & 0.82 & Twedt et al. (2002) & & \\
\hline CSWA & 0.42 & Duguay et al. (2001) & & \\
\hline DICK & 0.94 & Twedt et al. (2002) & & \\
\hline EAME & 0.72 & $\begin{array}{l}\text { Twedt et al. (2002), Wells et al. } \\
\text { (2007) }\end{array}$ & & \\
\hline
\end{tabular}




\begin{tabular}{|c|c|c|c|c|}
\hline Species & $\begin{array}{c}\text { Avg. } \\
\text { Nest } \\
\text { Surv\% }\end{array}$ & Nest Survival Reference(s) & $\begin{array}{c}\text { FY/nest } \\
\dagger\end{array}$ & FY/nest Reference(s) \\
\hline EATO & 0.40 & $\begin{array}{l}\text { Duguay et al. (2001), Twedt et al. } \\
\text { (2002) }\end{array}$ & & \\
\hline EAWP & 0.47 & $\begin{array}{l}\text { Twedt et al. (2002), Knutson et al. } \\
\text { (2006) }\end{array}$ & & \\
\hline GCFL & 0.78 & Knutson et al. (2006) & & \\
\hline GCWA & 0.62 & Reidy et al. (2008) & 3.60 & Reidy et al. (2008) \\
\hline GRCA & 0.45 & $\begin{array}{l}\text { Duguay et al. (2001), Peak et al. } \\
\text { (2004), Knutson et al. (2006) }\end{array}$ & & \\
\hline GWWA & 0.59 & Bulluck \& Buehler(2008) & & \\
\hline HOWA & 0.35 & $\begin{array}{l}\text { Duguay et al. (2001), Rush \& } \\
\text { Stutchbury (2008) }\end{array}$ & 2.67 & $\begin{array}{l}\text { Rush \& Stutchbury } \\
\text { (2008) }\end{array}$ \\
\hline HOWR & 0.64 & Knutson et al. (2006) & & \\
\hline INBU & 0.26 & $\begin{array}{l}\text { Duguay et al. (2001), Twedt et al. } \\
\text { (2001, 2002), Peak et al. (2004), } \\
\text { Knutson et al. (2006), Gram et al. } \\
\text { (2003) }\end{array}$ & & \\
\hline KEWA & 0.37 & $\begin{array}{l}\text { Peak et al. (2004), Gram et al. } \\
\text { (2003) }\end{array}$ & & \\
\hline LARB & 0.32 & Adams et al. (2007) & & \\
\hline Multi-SPS & 0.45 & $\begin{array}{l}\text { Weakland et al. (2002), King \& } \\
\text { DeGraaf (2002) }\end{array}$ & & \\
\hline MYWA & 0.67 & Dalley et al. (2008) & & \\
\hline NOCA & 0.29 & $\begin{array}{l}\text { Twedt et al. (2001, 2002), Peak et } \\
\text { al. (2004), Knutson et al. (2006) }\end{array}$ & & \\
\hline OVEN & 0.52 & $\begin{array}{l}\text { King et al. (1996), Duguay et al. } \\
\text { (2001), Borque \& Villard (2001), } \\
\text { Peak et al. (2004), Knutson et al. } \\
\text { (2006) }\end{array}$ & 4.30 & $\begin{array}{l}\text { King et al. (1996), } \\
\text { Porneluzi \& Faaborg } \\
\text { (1999), King \& } \\
\text { DeGraaf (2002), } \\
\text { Bayne \& Hobson } \\
\text { (2002), King et al. } \\
\text { (2006) }\end{array}$ \\
\hline PROW & 0.40 & $\begin{array}{l}\text { Duguay et al. (2001), Twedt et al. } \\
\text { (2002), Knutson et al. (2006) }\end{array}$ & & \\
\hline RBGR & 0.45 & $\begin{array}{l}\text { Duguay et al. (2001), Knutson et } \\
\text { al. (2006) }\end{array}$ & & \\
\hline REVI & 0.40 & $\begin{array}{l}\text { Duguay et al. (2001), Knutson et } \\
\text { al. (2006) }\end{array}$ & & \\
\hline
\end{tabular}




\begin{tabular}{|c|c|c|c|c|}
\hline Species & $\begin{array}{c}\text { Avg. } \\
\text { Nest } \\
\text { Surv\% }\end{array}$ & Nest Survival Reference(s) & $\begin{array}{c}\text { FY/nest } \\
\dagger\end{array}$ & FY/nest Reference(s) \\
\hline RTHU & 0.53 & Knutson et al. (2006) & & \\
\hline SCTA & 0.43 & $\begin{array}{l}\text { Duguay et al. (2001), Twedt et } \\
\text { al. (2002), Knutson et al. (2006) }\end{array}$ & & \\
\hline VEER & 0.48 & Duguay et al. (2001) & & \\
\hline VESP & 0.45 & Grant et al. (2006) & & \\
\hline WAVI & 0.31 & $\begin{array}{l}\text { Ward \& Smith (2000), Twedt et } \\
\text { al. (2002), Knutson et al. (2006) }\end{array}$ & & $\begin{array}{l}\text { Ward \& Smith } \\
(2000)\end{array}$ \\
\hline WEWA & 0.27 & Gram et al. (2003) & & \\
\hline WOTH & 0.46 & $\begin{array}{l}\text { Hoover et al. (1995), Anders et al. } \\
\text { (1997), Simons et al. (2000), } \\
\text { Duguay et al. (2001), Peak et al. } \\
\text { (2004), Knutson et al. (2006), } \\
\text { Kaiser \& Lindell (2007), Schmidt } \\
\text { et al. (2008) }\end{array}$ & 3.14 & $\begin{array}{l}\text { Anders et al. (1997), } \\
\text { Powell et al. (1999), } \\
\text { Fauth (2000), Simons } \\
\text { et al. (2000), Kaiser } \\
\text { \& Lindell (2007), } \\
\text { Schmidt et al. (2008) }\end{array}$ \\
\hline WTSP & 0.82 & Dalley et al. (2008) & & \\
\hline YHBL & & & 2.44 & $\begin{array}{l}\text { Willson et al. (1966), } \\
\text { Ward (2005) }\end{array}$ \\
\hline YWAR & 0.36 & Knutson et al. (2006) & & \\
\hline
\end{tabular}


Table A3.2. Literature-derived estimates of the probability of surviving from fledging to independence $\left(\mathrm{P}_{[\mathrm{FY}-\mathrm{IY}]}\right)$ and overwinter survival of juveniles $\left(\mathrm{P}_{[\mathrm{Sj}]}\right)$. Species codes are according to the AOU 2012 (Pyle and De Sante 2012).

\begin{tabular}{lllll}
\hline \hline Species & $\mathrm{P}_{[\mathrm{FY}-\mathrm{IY}]}$ & Reference for $\mathrm{P}_{[\mathrm{FY}-\mathrm{IY}]}$ & $\mathrm{P}_{[\mathrm{Sj}]}$ & Reference for $\left.\mathrm{P}_{[\mathrm{S}]}\right]$ \\
\hline HOWA & 0.190 & Rush \& Stutchbury (2008) & & \\
OVEN & 0.360 & King et al. (2006) & \multirow{2}{*}{0.680} & \\
WOTH & 0.423 & Anders et al. (1997) & & \\
Great Tits & 0.252 & Dhondt (1979) & & Sullivan (1989) \\
YEJU & 0.321 & Sullivan (1989) & 0.854 & Sullivan (1989) \\
YEJU & 0.577 & Sullivan (1989) & & \\
EUST & 0.429 & Kostecke \& Cimprich (2008) & & \\
DICK & 0.530 & Wells et al (2007) & & \\
EAME & 0.634 & Wells et al (2007) & & \\
WOTH & 0.690 & Schmidt et al. (2008) & & \\
LARB & 0.360 & Adams et al (2001) & & \\
YHBL & 0.360 & Ward (2005) & & \\
WEME & 0.690 & Kershner et al (2004) & & \\
LARB & 0.367 & Adams et al (2001) & & \\
\hline
\end{tabular}


Appendix 4. Density estimates (singing males/ha) of selected species taken from the national BAM dataset.

Table A4.1 Density estimates (singing males/ha) of selected species taken from the national BAM dataset. Only broad forest cover categories have been used of several habitat categories. Only data for BCR and province where a given species achieves its highest density are listed. These data illustrate how variable optimal species habitats can be across the country and by BCR and the challenge this represents in terms of making general statements about the importance of national forestry IT estimates. Species codes are according to the AOU 2012 (Pyle and De Sante 2012)

\begin{tabular}{|c|c|c|c|c|c|c|c|c|c|c|}
\hline Species & $\begin{array}{l}\text { Max } \\
\text { Density }\end{array}$ & $\begin{array}{l}\text { BCR } \\
\text { Avg. } \\
\text { density }\end{array}$ & Burns & Conifer & Deciduous & Mixedwood & $\begin{array}{l}\text { Mixed } \\
\text { Forest/Crop }\end{array}$ & $\begin{array}{l}\text { Open } \\
\text { Herb/Grass }\end{array}$ & $\begin{array}{l}\text { Open } \\
\text { Northern }\end{array}$ & $\begin{array}{l}\text { Poorly } \\
\text { Drained }\end{array}$ \\
\hline ALFL & 8-QC & 0.23 & 0.00 & 0.20 & 0.48 & 0.30 & 0.05 & 0.27 & 0.31 & 0.05 \\
\hline AMRE & 6-MB & 0.73 & 0.01 & 0.26 & 1.01 & 1.04 & 0.73 & 0.75 & 0.00 & 0.05 \\
\hline BAWW & 14-NS & 0.37 & 0.00 & 0.09 & 0.44 & 0.33 & 0.22 & 0.42 & 0.00 & 0.28 \\
\hline BBWA & 12-QC & 0.40 & 0.16 & 0.52 & 0.27 & 0.40 & 0.03 & 0.22 & 0.00 & 0.02 \\
\hline BLPW & 8-NL & 0.67 & 0.00 & 0.54 & 0.45 & 0.66 & 0.00 & 1.08 & 0.00 & 0.78 \\
\hline BTNW & 14-QC & 0.70 & 0.01 & 0.48 & 0.78 & 0.73 & 0.58 & 0.34 & 0.08 & 0.30 \\
\hline CAWA & 6-MB & 0.13 & 0.00 & 0.08 & 0.16 & 0.20 & 0.10 & 0.09 & 0.01 & 0.00 \\
\hline CMWA & 8-SK & 0.16 & 0.00 & 0.20 & 0.00 & 0.31 & 0.00 & 0.00 & 0.00 & 0.03 \\
\hline CONW & 14-NS & 0.57 & 0.01 & 0.62 & 0.56 & 0.65 & 0.33 & 0.47 & 0.10 & 0.09 \\
\hline LEFL & 12-QC & 0.10 & 0.16 & 0.02 & 0.19 & 0.11 & 0.10 & 0.01 & 0.01 & 0.00 \\
\hline MOWA & $12-\mathrm{ON}$ & 0.53 & 0.01 & 0.43 & 0.50 & 0.61 & 0.20 & 0.31 & 0.09 & 0.02 \\
\hline OVEN & $7-\mathrm{ON}$ & 0.25 & 0.13 & 0.17 & 0.06 & 0.27 & 0.00 & 0.11 & 0.07 & 0.34 \\
\hline PAWA & 8-QC & 0.81 & 0.04 & 0.95 & 0.38 & 0.73 & 0.02 & 1.01 & 0.06 & 0.62 \\
\hline RCKI & 4-YT & 0.97 & 0.00 & 1.36 & 0.19 & 1.27 & 0.13 & 1.18 & 0.71 & 0.82 \\
\hline SWTH & 6-SK & 0.65 & 0.20 & 0.13 & 0.26 & 0.32 & 0.11 & 0.20 & 0.36 & 0.84 \\
\hline TEWA & 8-NL & 0.82 & 0.02 & 0.42 & 1.48 & 0.84 & 0.45 & 0.85 & 0.28 & 0.81 \\
\hline WTSP & 4-YT & 1.46 & 0.16 & 2.12 & 0.11 & 1.06 & 0.27 & 1.70 & 1.14 & 0.84 \\
\hline YRWA & 8-QC & 0.23 & 0.00 & 0.20 & 0.48 & 0.30 & 0.05 & 0.27 & 0.31 & 0.05 \\
\hline
\end{tabular}

